\title{
Rajnarayan Basu and His "Science of Religion": The Emergence of Religious Studies through Exchanges between Bengali and Christian Reformers, Orientalists, and Theosophists
}

\author{
Julian Strube \\ Assistant Professor, Department of Religious Studies, \\ University of Vienna, Vienna, Austria \\ julian.strube@univie.ac.at
}

\begin{abstract}
This article explores the genealogy of the "science of religion" developed by the Bengali intellectual Rajnarayan Basu (1826-1899). One of my central aims is to demonstrate that a "science of religion," or Religionswissenschaft in the sense of Friedrich Max Müller, has emerged within a global context that was actively shaped by "non-Western" actors. To this end, I will focus on exchanges between the Indian reform movement of the Brahmo Samaj, Christian Unitarians, Transcendentalists, orientalist scholars, and members of the Theosophical Society. All these actors were concerned with the origin of religion, its modern meaning, and its function in shaping the future of society. Building on an analysis of the global exchanges revolving around these issues, special attention is paid to the inherent tensions between religious universalism and a nationalist insistence on "true religion," which directly pertains to contested demarcations between reform and revival, or modernity and tradition.
\end{abstract}

\section{Keywords}

colonialIndia-reform movements-Unitarianism-Orientalism-esotericism-science of religion 


\section{A Global Perspective on Negotiations of Religion, Science, and Esotericism}

In what follows, I will examine a tangle of exchanges between the Bengali "reform" movement of the Brāhma Samāj, "progressive" Christian Unitarians, European orientalists, and members of the Theosophical Society. These exchanges revolved around the meaning of "true" religion, its relationship to science, and the issues of Hindu national identity within the context of colonialism. A global perspective helps to explore and explain the significant overlaps, as well as disagreements, between the viewpoints of the vastly different participants in these exchanges, which gave shape to the emerging discipline now known as religious studies. The focus of my exploration rests on nineteenth-century Bengal, where global debates about the meaning of religion were inherently intertwined with Indian struggles about the meaning of dharma. It will become evident that Rajnarayan Basu was an important historical actor in the broader history of religion, due to his specific contribution to science, religion, and reform that cannot simply be considered a "reception of Western thought." I will illustrate this by relating global connections, which in this case manifested primarily through journals and pamphlets, to the regional context of Bengal and the issues surrounding "reform," "revival," "true religion," and dharma.

This allows for the operationalization of a number of theoretical and methodological aspects that are essential to global religious history and are further detailed in the introduction to this issue (Maltese \& Strube 2021; cf. Strube forthcoming-b). These include the notion of entanglement, which reflects the nature of the exchanges under scrutiny that were neither unidirectional nor determined by clearly distinguishable factions such as East and West, Western and Indian, Hindu and non-Hindu, reformist and orthodox, traditional and modern, or colonizer and colonized. Instead, the reader will encounter a metaphorical tangle of diverse and changing individuals and groups whose identities and ideas were interdependently formed and altered through exchanges. This can be especially well illustrated through the consideration of Theosophy as represented by Helena Petrovna Blavatsky (1831-1891) and Henry Steel Olcott (1832-1907), in addition to the well-documented contact between orientalists such as Friedrich Max Müller (1823-1900), Transcendentalists, Unitarians, and Brahmos. In light of these examples, the perspective proposed by global religious history not only helps to overcome the Eurocentric modes of historiography, which still dominate the scholarship on Theosophy or "esotericism" more broadly, but also the exaggerated reduction of exchanges that occurred in colonial contexts to "appropriation." Both tend to eclipse the agency of 
the colonized, imply notions of (precolonial or "premodern") authenticity, and sometimes even call for a separation of "Western" and "indigenous" historiographies.

Indeed, Theosophy provides the opportunity to critically address two extremes in the global historiography of the colonial period. On the one hand, research on Theosophy is mainly conducted within the field of "Western esotericism," whose predominant conceptualization rests on a diffusionist model that I have criticized in detail elsewhere (Strube 2021). Wouter Hanegraaff, a leading proponent of the field, has maintained that "originally European esoteric or occultist ideas and practices have now spread all over the globe," resulting in "mutations" of those ideas that "traveled back to the West, only to be (mis)understood there as the 'authentic' voices of non-Western spiritualities." Consequently, Hanegraaff stresses the "globalization of Western (!) esotericism" (2015: 86, original emphasis). On the other hand, some Indian scholars, such as Ashis Nandy or Vinay Lal, have criticized global historical approaches for participating in a masked imperialistic project (Nandy 1996; Lal 2003). As Harald Fischer-Tiné has pointed out, these critics "stress the uniqueness and incommensurability of South Asia and its past, rather than its embeddedness in broader global structures or processes" (Fischer-Tiné 2018: 55). Such antiglobal historical viewpoints are paralleled by Hanegraaff's insistence that an investigation of esotericism outside "the West" would constitute a "terminological imperialism if we now tried to project this terminology on to the rest of the world" (Hanegraaff 2015: 86). In both extreme cases, global connections and the agency of colonized, "non-Western" people within them are effectively obscured (cf. the introduction to this issue).

It is such historiographical binaries and claims of incommensurability that global religious history and its elaboration on global entanglement and connections aims to overcome. This can only be achieved if all participants in global exchanges are investigated in their own right. Historians would be ill-advised to retreat to "vernacular" historiographies when faced with colonial conquest, oppression, and exploitation, as this would replicate the very dichotomies that non-Eurocentric scholarship should complicate. Genealogy, as conceptualized in global religious history, proves to be specifically helpful in this regard: historically, "non-Western" actors have used the language of esotericism to describe their practices and ideas since it emerged in the nineteenth century (Bergunder 202ob; cf. Bergunder 2014b: 275-279). As is the case with religion, esotericism was and is used globally from the beginning (Strube forthcominga), and controversies about its "Western specificity" (Hanegraaff 2015: 82) owe themselves to the insistence on its origins in Europe and links this claim with one of ownership, a prerequisite for export. These concerns pertain to issues 
that extend far beyond the subjects that have hitherto been studied under the label of "Western esotericism": Michael Bergunder has argued that the debates about the meaning of "religion" and "esotericism" were inherently intertwined throughout the nineteenth century - he speaks, in fact, of their "twin birth" (Bergunder 2o2ob: 56). Indeed, the following sources will demonstrate that the study of esotericism sheds important light on the global struggle for the meaning of religion, and its relationship to science and philosophy.

Global historians, in particular, could profit from considering the generally neglected subject of Theosophy, as its paramount importance for nineteenthcentury religious and global history is often acknowledged but not discussed in detail (e.g., Bayly 2004: 365; Osterhammel 2014: 813; Conrad 2018: 582-584). The same applies to South Asian studies, where the importance of Theosophy for "Hindu revivalism" and Indian politics in general is frequently emphasized but rarely dwelt on (e.g., Raychaudhuri 1988: 10, 33; Sen 1993: 5; Bhatia 2017: $5^{8-59}$, 127; see, in contrast, Bhatia 2020; Mukhopadhyay 2020). Despite some important steps in this direction (Green 2015), only one volume to date has approached Theosophy from a global perspective (Krämer \& Strube 2020).

This lack of engagement between different fields of study means there is still great potential in a more ambitious collaboration between religious studies and global history. Both disciplines are relatively new and significantly occupied with the fact that the meanings of both "global" and "religion" are anything but clear. In fact, these disciplines derive many of their strengths from the very need to constantly reflect on, debate, and refine their approaches. If one of the central arguments of global religious history is taken seriously - namely that the meanings of "religion" and "esotericism," and their positioning towards "science" and "philosophy," have been crucially negotiated and shaped during the nineteenth century - combining the toolkits of religious studies and global history holds great potential.

One tool that would be particularly useful is the notion of agency. In what follows, I will concentrate on historical actors, that is, human beings whose actions shape history and whose capacities and limits for doing so are determined by contextual circumstances (cf. Wenzlhuemer 2017: 145). Global connections emerge from people's actions, or the potential for their actions, and hence from the tangible and empirically examinable sources they produce. Historical actors create and change (e.g., institutional or societal) structures; they form the nodal points for global connections and give them both substance and power. At the same time, it is through their examination that the limits and boundaries of agency can be studied and interpreted. An actorcentered approach thus operates as an analytical prism that brings to light a wider spectrum of patterns of global connections and makes sense of the 
many overlapping and fluid layers of meaning of events and their contexts (Wenzlhuemer 2017: 148-149, 184-185). The study of relevant sources requires concrete philological, theoretical, and methodological toolkits. In the introduction to this issue, Giovanni Maltese and I have made a comprehensive proposal for a substantiated approach to global entanglement, connections, and agency.

The crucial point is that the debates about "true" and "universal" religion, as well as about "reform" and "revival," unfolded within a global context and were decidedly marked, not simply through the passive reception of Western knowledge, but through the agency of Indians. As I will argue in what follows, this becomes tangible through the interconnectedness of Brahmo, Unitarian, Transcendentalist, Theist, Theosophical, and orientalist approaches to religion. They were indeed the outcome of tangled, dynamic exchanges that defy binaries and dichotomies. Their many ambiguities, contradictions, and ruptures necessarily disrupt simple narratives and clear-cut identities: that is, they provide instructive insights into the complexities of human interaction and knowledge production in a time when monolithic and polarized identities are the subject of both public and academic debate.

Tensions between Brahmo Universalism and Nationalism: Rajnarayan Basu

The Brāhma Samāj must be counted among the most influential cultural forces in colonial India. Concerned with social reform and the propagation of a universal religion, Brahmos strived for the purification and restoration of dharma, while at the same time propagating its harmony with "modern scientific" rationalism. While Brahmoism was dominated by a universalist thrust in the first half of the nineteenth century, the second half saw growing nationalist tendencies and several schisms, contributing to Brahmoism's waning significance towards the end of the century. Its immediate roots reach back to the Calcutta Unitarian Committee, which was founded in 1823 by the famous learned Bengalis Rammohan Roy and Dvarkanath Tagore, together with the former Scottish Baptist missionary William Adam. This collaboration between reform-minded Indian intellectuals and Unitarians was sparked by the publication of Rammohan's Precepts of Jesus, a compilation of the ethical teachings of Christ (Kopf 1979: 7-8; Zastoupil 2010: 39-56). Rammohan's universalistic and rationalistic approach to different religions was shaped by his Persian education and further developed through his engagement with orientalist scholarship and Western philosophy (Zastoupil 2010: 25-26; Hatcher 2020: 225-226). 
He maintained that Upanishadic Vedanta contained the essence of Vedic truth but had to be purged of its supposed superstitious, irrational, and idolatrous aberrations. This point of view contributed decisively to the formation of the widespread modern perception of Hinduism, with Vedanta as its underlying philosophy and the Bhagavadgit $\bar{a}$ as a central scripture (Bergunder 2006; also see Jackson 1981: 69-73, 113; Versluis 1993: 99-104, 197).

Rammohan's interactions with the Unitarians paved the way for a rich and lasting exchange between the United States, Europe, and India that peaked during the second half of the nineteenth century (Lavan 1977). One outcome was that Unitarianism became a major influence on the tenor of the reform debates in early-nineteenth-century Calcutta (Hatcher 1999: 104). In turn, this led to the transformation of Unitarianism into the universal current that eventually motivated the famous Parliament of the World's Religions of 1893: in the words of David Kopf, liberal Unitarianism emerged out of the "parallel experiences of like-minded individuals in Boston, Bristol, and Calcutta" (Kopf 1979: 4-5). This development also shaped American Transcendentalism and led to a vast project of comparative religion that gained further momentum in the second half of the century (Jackson 1981, cf. Versluis 1993: 235-328). Müller, who is often credited with the establishment of comparative religion and the "science of religion" (Müller 1873) discussed below, regarded Rammohan as the founder of comparative religion and corresponded with leading Brahmos (Stevens 2018: 179-181). This demonstrates that the emergence of a "science of religion," or Religionswissenschaft, can only be fully grasped when these global exchanges are considered.

Rammohan created the Brāhma Sabhā in 1828 to promote his ideas and attract like-minded individuals. After his unexpected death during a visit to some Unitarian friends in Bristol in 1833, the society lay dormant. Its resurrection began in 1839, when Debendranath Tagore, son of Dvarkanath and father of several eminent intellectuals including Rabindranath Tagore, established the Tattvabodhinī Sabhā (Truth-Seeker Society). Less occupied with Christianity, it emphasized the promotion of the ultimate truth (tattva) based on the Upanishads (Hatcher 2006). In 1843, Debendranath effectively resurrected the Brāhma Samāj by associating it with his Sabhā (Kopf 1979: 161-163). The society then took up ardent missionary activities and propagated its ideals in widely distributed journals, most notably the Tattvabodhinī Patrikā, which was also started in 1843 (Raychaudhuri 1988: 7). Brahmos largely consisted of the English-educated Bengali middle class known as bhadralok. They propagated what Hatcher has termed "bourgeois Hinduism," a mélange of Vedantic teachings, rationalistic monotheism, religious universalism, public education, and social reforms that included allowing widows to remarry and prohibiting 
child marriage (Hatcher 2007: 7-9; Hatcher 2008: 7-10). The Brahmos maintained both Rammohan's universalism and his dedication to the ancient roots of Indian religion, but increasingly employed the arguments of natural theology, thus opening up the world to exegesis and effectively admitting "the possibility of deriving truths from the evidence that might be found in the record of humanity's religious experience" (Hatcher 1999: 105; Hatcher 1996: 212-240). By engaging with religious scriptures in this way, they aimed to prove that Brahmoism was, in fact, the universal religion.

Rajnarayan Basu became one of the leading voices among the increasingly fragmented Brahmo movement in the second half of the nineteenth century. He was born in 1826 in a village of the district 24 Parganas and was, unlike the majority of Brahmos, no Brahman but a Kayastha. The grandfather of the famous revolutionary-turned-spiritual leader Aurobindo Ghosh, he was prominently dubbed the "grandfather of nationalism in India" (Sarkar 1909), which already hints at the tensions between nationalism and universalism that will come under scrutiny below. Rajnarayan's father Nandakishor was among the earliest followers of Rammohan. He was one of the first students of Rammohan's Vedantic Academy and served as his secretary for a time (Basu 1909: 6-8). In 1833, Rajnarayan was sent to Calcutta to the renowned school run by David Hare, a staunchly atheistic educator whose harsh and even traumatizing treatment is bitterly recalled by his pupil (Basu 19o9: 12-13). At the Hindu College, Rajnarayan ardently read Western literature, philosophy, and history (Basu 1909: 27-28). He joined the Young Bengal movement, which was aggressively rationalistic, often atheistic and secular in outlook. Formed in 1828 , the movement enthusiastically engaged with Western authors and occupied itself with issues including social reform, the position of women, patriotism, and education (Hatcher 2008: 28-29; Chatterjee 2010: 146-147). It faded in 1843, parallel to the re-establishment of the Brāhma Samāj by Debendranath. Rajnarayan did not look back fondly on this period in his life, recalling how his excessive consumption of wine drove him to leave the college (Basu 1909: 41-42).

The death of his father in 1845 plunged him into a deep crisis. From early on, he had been exposed to Rammohan's "Universal Religion" (Basu 19o9: 30, given in English and then as biśvajanin dharma) and he immersed himself in the Precepts of Jesus and the Unitarian writings of William Channing, whose progressive thought was highly popular in Bengal (Kopf 1979: 4-6). Departing from his Young Bengal background, his path to Brahmoism was anything but straightforward: "I became a Unitarian Christian, then somewhat of a Muslim [ịṣat. musallmān]" (Basu 19o9: 39). In 1846, he eventually found a patron in Debendranath and took the oath to become a Brahmo (Basu 1909: 46). He 
was hired by Debendranath to do an English translation of the Upanishads, while at the same time engaging with the work of August Wilhelm Schlegel (Basu 1909: 50-51).

Within several years, Rajnarayan developed into one of the most prolific and influential Bengali authors. In order to understand his further activities, it is important to consider two crucial contextual aspects. The first aspect is the Brahmo struggle against Christian missionary polemics from the mid-184os combined with the advancement of Rajnarayan's own missionary agenda. Among those taking a stance against Christian criticism, Rajnarayan distinguished himself as a fiery defender of hindu dharma. His fight culminated in his famous lecture on "The Superiority of Hinduism" (Hindudharmmer śreșthatā) in 1872, which will be discussed in more detail below (cf. Kopf 1974: 16; Hatcher 1999: 111-112; Hatcher 2008: 19). In his defense, Rajnarayan followed Rammohan's proclamation of Vedanta as "Hindu Theism," implying that Hinduism has a monotheistic core consistent with that of Christianity, Islam, and Judaism. This pure Vedanta, which was later corrupted by idolatry, polytheism, and superstition, could be found in the Upanishads and the Brahma Sütras in particular. When the Scottish Presbyterian missionary Alexander Duff launched an attack on Vedanta, Rajnarayan countered in the Tattvabodhin $\bar{\imath}$ Patrikā, arguing that Vedantic Theism was not a modern product but a return to the "Unitarian," monotheistic religion of the ancient Vedas, which, at the same time, perfectly harmonized with modern rationalism and natural theology (Kopf 1974: 15-16; Hatcher 1999: 112-113). The crucial point is that, from early on, Rajnarayan began to define Brahmoism as Hindu Theism and position it as a manifestation of universal religion that was superior to those of his critics.

The second aspect that significantly influenced Rajnarayan's missionary agenda was the internal rivalries and schisms among the Brahmos themselves. The scope of this article only allows for the shining of a spotlight on one pivotal actor within a highly complex development, namely Keshabchandra Sen (1838-1884), who joined the Brāhma Samāj in 1857 after having formed a friendship with the Unitarian missionary Charles Dall in 1855 (Stevens 2018: 30). Keshab enthusiastically embraced Unitarianism and praised the virtues of Christianity, which motivated the celebrated scholar and secular reformer Ishvarchandra Vidyasagar to leave the Tattvabodhinī Sabhā in 1859, escalating the simmering conflicts within the Brahmo milieu. When Keshab founded his Brāhma Samāj of India (Bhārat'barṣịya Brāhma Samāj) in 1866, more schisms ensued. As Debendranath's successor, Rajnarayan now functioned as the leader of the Ādi ("original") Brāhma Samāj (Kopf 1979: 179; Stevens 2018: 115-153). After a journey to England in 1870, Keshab established the Indian Reform Association to promote "the social and moral reformation of the 
Natives of India" while maintaining close contacts with the social reformist Free Religious Association, which had grown out of Unitarianism in 1867 and strived for the creation of a scientific religion on the basis of religious comparativism (Jackson 1981: 103-122; cf. Robinson 2015; Gura 2007; Myerson et al. 2010; the global connections of Keshab's thought have been further explored by Banerjee 2018: 118-128).

Müller observed these developments with great interest and expressed his "full faith" in Keshab when he established the Nababidhān or New Dispensation Church in 1879 (Müller 19o2: 59). The latter's members proclaimed a universal religion headed by Keshab as a prophet or avatar. One of his followers, Pratapchandra Majumdar, would later be invited by the Unitarians to become a member of the Advisory Council and Selection Committee for the 1893 Parliament of the World's Religions and develop an extensive missionary endeavor in the United States (Mullick 2010). In his correspondence with Pratapchandra, Müller proposed that the Brahmos join the Church of England and refer to themselves as "Christian Brahmos, or Christian Aryas" (Müller 19o2: 391, 397). Given Rajnarayan's fiery defense of Hindu Theism against Christian critics, Keshab's embrace of Christianity only deepened the rift between the Brahmo factions.

These developments decisively contributed to Rajnarayan's shift in emphasis from the proclamation of a universal religion to the superiority of Hinduism within a plurality of tolerated religions, all of which contained elements of truth and diverged according to what was considered appropriate for its socalled "nationally different" followers. Rajnarayan's defense of hindu dharma was ambivalent, as contemporaries usually viewed "Hindus" and "Brahmos" as two distinct cohorts. His stance was possible because, while he did proclaim the existence of a universal "essential religion" (sārldharma), he also positioned Hindu Theism, that is the true hindu dharma, as the most superior development of it. It is clear that both universalist and nationalist tendencies have been an integral part of Rajnarayan's thought from early on. Yet, it can be observed how the nationalist and "Hindu revivalist" sentiments moved increasingly to the fore (cf. Sen 1993: $55^{-56}$ ).

In the early 186os, Rajnarayan called for the establishment of what he termed the Society for the Promotion of National Glory (Jātìya Gaurab Sañcārinī Sabhā), which would inspire Nabagopal Mitra for the inaugural celebration of the famous Hindu Mela in 1867, widely considered the first major manifestation of Hindu nationalism (Basu 1909: 83; Gupta 2009: 20-21). In 1866, when Keshab established his breakaway Samāj, Rajnarayan published the Prospectus of a Society for the Promotion of National Feeling among the Educated Natives of Bengal (Kopf 1974: 22; Kopf 1979: 179-180; Hatcher 1999: 106-111; Stevens 2018: 
175). In the pamphlet, Rajnarayan called for a "reform in national shape," reprimanding Bengalis for renouncing the Hindu name because of a "desire for change and progress," which threatened to "sweep away whatever good we have inherited from our ancestors. [...] Without due cultivation of national feeling, no nation can be eventually great" (Chatterjee 1986: 225).

Most importantly, Rajnarayan insisted on the advancement of the Bengali language in order to counter what was perceived as a destructive "Anglo-mania." He believed that children should be educated in their mother tongue first and the use of Bengali was encouraged both in everyday and official affairs (quoted after Chatterjee 1986: 227-230). At the same time, the society sought to "publish in the Bengali the results of the researches of the Sanskrit scholars of Europe [...] giving special prominence to their descriptions of prosperity and glory of ancient India." In cooperation with the Asiatic Society of Bengal, it also promoted the cultivation of Sanskrit (Chatterjee 1986: 227). Although the society did not want to take an active part in "social reformation," it wished to provide "proofs of the existence of liberal and enlightened customs in Ancient India, such as female education, personal liberty of females, marriage by election of the bride, marriage at adult age, widow-marriage, inter-marriage, and voyage to distant countries" (Chatterjee 1986: 230-231).

Rajnarayan's nationalist outlook further hardened in a brochure from 1870 about The Adi Brahma Samaj: Its Views and Principles. Therein he continued to insist on the "extreme liberality and catholic character" of the Brahmo doctrine, but his attacks were now primarily directed against Keshab, rather than Christian missionaries. Moreover, it becomes obvious that he was concerned with bridging the gap between Brahmos and other Hindus with more conservative leanings (cf. Kopf 1974: 22-23). The tension between Rajnarayan's universalism and nationalism becomes especially apparent in his declaration that ...

Brahmaism is universal religion; that it is confined to no particular age, nation, sect or individual; that it is not the exclusive property of the ancients or moderns, the Hindu or the Mlechchha, of Vyas or Christ, Zoroaster, or Confucius; but that its truths are to be found in the Scriptures of all nations and the writings of the pious men of all ages and countries and that all nations have a claim to a participation of the spiritual benefits which as the air of heaven it imparts to all mankind without distinction.

The members of the Adi Samaj, aiming to diffuse the truths of Theism among their own nation, the Hindus, has [sic!] naturally adopted a Hindu mode of propagation just as an Arab Theist would adopt an Arabian mode 
of propagation and a Chinese Theist a Chinese one. Such differences in the aspect of Theism in different countries must naturally arise from the usual course of things but they are adventitious, not essential - national, not sectarian.

BASU 1870: 1-2

It is against this background that Rajnarayan developed his "science of religion," which he actively promulgated in subsequent years. On the one hand, it can be understood as a continuation of the universalist and comparative program that had developed since the time of Rammohan and effectively laid the foundation for the comparative study of religion. On the other hand, it was an integral part of Rajnarayan's apology of Hindu Theism, the perfect way to access pure religious truth.

\section{3}

Rajnarayan's Science of Religion

Rajnarayan's concept of a "science of religion" took shape already within his early writings. For instance, in his 1863 Defence of Brahmoism, which was, as the title suggests, still primarily directed against missionary adversaries. Therein, Rajnarayan invoked the "science of theology" to argue that the "grand edifice of Theism" was most perfectly expressed by Brahmoism, the universal religion wherein there is no conflict between science and religion (Basu 1863: 24). As mentioned above, Rajnarayan referred to the concept of sārldharma or "essential religion" throughout the 186 os in order to prove the superiority of Brahmoism, a notion that he would continue to develop in subsequent years. In an 1886 collection of earlier English (Bose 1886a) and Bengali (Bose 1886b) writings, he quoted liberally from the Kațhopanișad, the Bhagavadgitā, Sanskrit hymns, the New Testament, the Koran, Hafez, Attar, Rammohan, the Methodist Charles Wesley, and the leading figure of the Oxford Movement, Edward Pusey. His enthusiastic references to the Unitarian Theodore Parker, whose collected works had been published in Bengali in 1866 and were extraordinarily influential among Brahmos, mark an especially significant influence (Kopf 1979: 27, 30; Stevens 2018: 49).

Rajnarayan insisted that the "Love of God and Love of Man constitute the essence of religion," and that "men's attention should be drawn from the nonessentials or the husk of religion to its essentials which form its kernel. Nothing has done so much mischief to the world as religious bigotry and dogmatism on non-essential points of religion" (Bose 1886a: 2; cf. Bose 1886b: 4-5, where the term for love is prem; cf. Basu 1866: $78-93$ ). Yet, he included the caveat that 
not all religions share this kernel of truth. Quoting Parker, he insisted that even adherents of "immoral idolatrous religions" have been observed leading pure and blameless lives in practice: "On the whole, however, those religions can not be included in the category of religion. Excluding them, all religions, whether polytheistic or monotheistic, that inculcate the love of God and the love of man, are paths to salvation, straight or devious, according to the amount of religious truth which each contains" (Bose 1886a: 3 ). Thus, Rajnarayan effectively posited a hierarchy of religions according to their degree of truth. When he quoted Parker as saying "there is only one ocean so there is only one religion," the statement was limited to those creeds that were thought to contain truth.

At the same time, Rajnarayan repeatedly stressed the "astonishing agreement between the pious sayings of pious men of all ages and countries," even among "such pious idolaters" (Bose 1886b: 2, pauttalik-dharma-sangitt) as Ramprasad of Bengal, Tulsidas of Upper India, and Tukaram of Maharashtra. Whether Brahmo, idolatrous Hindu, Muslim, or Christian: all could participate in the worship of God (iśsvarer upāsanā). Indeed, many learned Christians in Europe now frankly admitted that there is truth in other religions as well; and according to Muslim Sufis, all people worship the One God (parameśvar) in different manners (Bose 1886b: $5^{-6}$ ). Rajnarayan thus affirmed that "we are apt to lose sight of [the essentials of religion] in the mists of sectarian prejudice, partiality and passion," and that people tended to forget that they are not infallible, that the religious opinions of man are subject to progress, and that they will not be the same a century afterwards as they are now (Bose 1886a: 4-5; Bose 1886b: 13). Rajnarayan condemned sectarianism (Bose 1886b: 4, sāmpradāyikatā) and claimed that the reason why sceptics (samiśay'bādìrāa) could slander religion is that people are so preoccupied with opinion, they do not pay attention to the true religion (prakrta dharma) - too many people only pay attention to the shell (khos $\bar{a}$ ) of religion, not to its core (śãs) (Bose 1886b: 2-3).

Rajnarayan's resolution to this apparent contradiction between particularism and universalism was an insistence on individual and national preferences and qualifications: "Every individual man cannot avoid joining a sect according to his own particular convictions." Differences of religion must always exist in the world, as it is "impossible to bring over men to one and the same religion." While all religions should be tolerated, Rajnarayan was careful to emphasize that they contain either more or less truth, due to the errors arising from human imperfection (Bose 1886a: 8-9). Yet, no dharma was "as liberal" (udār) as hindu dharma (Bose 1886b: 7). After bemoaning the schisms among Brahmos, Rajnarayan maintained that the Theistic principles of the Ādi Brāhma Samāj were best suited to "strengthening the bonds of union between 
men of all religious persuasions and creeds," as "all religions are merely helps to the Essential Religion" (Bose 1886b: 10). It is quite striking to observe how much the focus shifted towards polemics against inter-Brahmo rivalries and the attempt to consolidate the representatives of Brahmoism and hindu dharma. This is also evident in Rajnarayan's pamphlet from 1870, wherein the "Avatarism and hero-worship" of Keshab and his followers are juxtaposed to the "extreme purity" of the "Theism of the Adi Samaj, being the legitimate result of the higher teachings of the Vedas as contained in the Upanishads" (Basu 1870: 10-11).

It is crucial to be aware of this context when we turn to Rajnarayan's remarkable publication from 1878: Hints Shewing the Feasibility of Constructing a Science of Religion, which was largely based on his much more extensive Dharmmatattvadīpika from 1866. Taking these two writings together is particularly instructive because the Hints introduce an explicitly comparative agenda to the earlier, thoroughly philosophical "illumination of the true meaning of dharma" (i.e., dharmatattvadīikā). In his two volumes from 1866, Rajnarayan was mainly occupied with expounding the epistemological means for establishing the true dharma, which was, obviously, brähmadharma. While "faith is the innate dharma of man" ("viśvās manuṣyer svabhāblsīddha dharmma"), there were two types of it: intuitive belief (ātmapratyay) and belief rooted in reason (yuktimülak pratyay்). Intuitive belief exists in all lands and is acquired through intuition (sahaj-jñān) (Basu 1866: 1-3). Therefore, it is through intuition that we can arrive at the "general belief" (sādhäran pratyay) of humanity (Basu 1866: 6-7). The faculties of the mind (manobrtti) are the root of belief, and it is the mind that allows us to discern what is true or false (satyal mithyā); the true principles of God (iśvarltattva, equivalent to "theology") can only be established by a sophisticated blend of intuitive belief and reason (Basu 1866: 15-30).

It bears noting that, unlike most contemporary authors of comparative religion, Rajnarayan explained his argumentation through epistemology, not through history and tradition. In fact, he emphasized that the belief in God, which is the root of all dharma, was not rooted in tradition ("paramparāgata-prabād-mūlak nahe") but inherent to all human beings; nor did it arise from sheer imagination (kalpanā) (Basu 1866: 17-18). What Rajnarayan understood as theology (his translation of isvarltattva) was, then, not established through a posteriori reasoning (käryyamūlak yukti), but through intuition (ātmapratyay்) and a priori reasoning (bhāblmūlak yukti) in combination with natural science (bijñān) (Basu 1866: 31). He emphasized the firm relationship between the knowledge of worldly things (jagatĩya padārthēr jñān) - that is science and a posteriori reasoning - and the "rise of 
knowledge about God" (iśvarljñānōdaỳ). Science was "necessary for the growth and refining of the determination of dharmatattva," but intuitive belief constituted by intelligence and conscience (buddhi o vivek) was the main root of knowledge of God: "Without this intuitive belief, how far is reason able to go?" (Basu 1866: 38).

It was on these grounds that Rajnarayan argued for "the authenticity of the science of Brahma" (brahmavidyār prāmānikatva), which he held was as valid as physical science, psychology, and other modern sciences (Basu 1866: 74-77). Just like physical scientists believed in the existence of energy (notably, śakti) even though it is invisible to the senses, the power that is God is real, even though it is beyond sensual perception (atīndrija padārtha) (Basu 1866: 1, 74; the role of Shaktism in Rajnarayan's epistemology would warrant a dedicated study). Eventually, all forms of science (vijñān-śāstra) are rooted in intuitive belief and are hence conditioned by the same faculty as knowledge of God (Basu 1866: 23). Rajnarayan was keen to insist, however, that there is only one true dharma (satyadharma), namely Brahmoism, which preached the "brotherhood of man [manusyer bhrātrontva] resulting from the fatherhood of God and was in total agreement with both intuitive belief and reason, with both the heart (hrday) and science: 'This dharma is modern yet ancient"” ("e dharmma ādhunik athaca prācīn") (Basu 1866: 103-109).

Given this broad epistemological foundation and how "modern science" served to elucidate the intuitive belief that is common to all people, despite having manifested and developed differently in each "nation" ( jāti), Rajnarayan fleshed out his proposal for a "science of religion" in 1878. Tellingly, the brochure is framed by epigraphs from the Māndūkya Upanișad, Max Müller's Introduction to the Science of Religion (1873), and Francis William Newman's Theism (1858). This outspoken invocation of "Western" and "Eastern" authorities is further underlined in the preface: "We can reasonably expect the rise of a Newton of Religion at no very distant period, seeing the attention which learned men have lately begun to pay to the subject of the Science of Religion, both in Europe and America." At the same time, Rajnarayan emphasized that he "derived some of his ideas on the subject from Sanskrit sources." Much of the Hints directly drew from Dharmmatattvadīpika and, as before, Rajnarayan defined "religion" (dharma) as the universal sentiment of depending on "something super-worldly." Quoting Parker, he asserted that this was the "original knowledge" common to humanity (Bose 1878: 1-4). Since Theism "discards revelation, it should attempt to place religion on a scientific basis to give a character of certainty to its assertions" (Bose 1878:1). As in 1866, Rajnarayan held that God was the subject of perception like other subjects of mind, and that knowledge of God was not only derived from intuition, but also "from Nature" 
(Bose 1878: 7), it followed that "hyper-physical perception" required correction and guidance through reason in order to provide accurate knowledge (Bose 1878: 9-10).

When developing his science of religion, Rajnarayan maintained close contacts with Unitarians and Theists, including the reformers and feminists Mary Carpenter, Frances Cobbe, and Emily Sharpe, with all of whom he corresponded extensively (Basu 19o9: 112, 144-159, 157, 159-182). After he received Rajnarayan's writings from Sharpe, the English Theist Charles Voysey wrote to him: "I want to place you in my gallery along with Theodore Parker, Professor Newman and Miss Cobbe. But you are a truer theist than any of them except Newman" (Basu 1909: 141). Indeed, Newman's presence can be felt in the Hints, and the significant parallels between the men's writings warrant further study. Both emphasized intuition and love as fundamental to religion, while insisting on science as its "bony frame-work" or "fabric" (e.g., Bose 1878: 1-3, 33-37; Newman 1858: 21). Both claimed that science and religion required certain "axioms" and that neither could depend on "pure reason" alone (Bose 1878: 2-3, 8; Newman 1858: 25-26); they rejected bigotry, superstition, idolatry, magic, and polytheism, with Newman proclaiming the creation of a "New Science": "This again is a vast service performed by Science to Religion / Which stands by Truth alone, in love of Truth, and by Free Thought" (Newman 1858: 20-21, 26). Similar to Rajnarayan, Newman defined God as conscience, energy, and power (Newman 1858:12-16), and praised the "essential foundations of religion in which Christians, Jews and Mussulmans agree" (Newman 1858: 121). Like the Bengali Brahmo, he highlighted "men's religious diversity" and individualism but promised that which Rajnarayan chose as the epigraph for the title page of his Hints: "when Religion shall become Science, disagreements will lessen" (Newman 1858: 52).

Rajnarayan's discussion of the beliefs of the "Ancient Aryans of India," which he linked to those of the ancient Greeks (Bose 1878:6), is especially noteworthy. This opens up a historical dimension in Rajnarayan's line of argument that is particularly relevant in light of the prominence he gave to Müller's Introduction. Like virtually all English-educated bhadralok, Rajnarayan was well familiar with the widespread theory that both Indians and Europeans descended from a common "Aryan" root. This becomes tangible in his polemics against missionaries, most notably the convert Krishnamohan Bannerji, who was one of Rajnarayan's earliest and ablest adversaries (Kopf 1974: 16-20). As recently as 1875, Bannerji published a monograph titled The Arian Witness, wherein he laid out a theory based on "comparative philology" (as Müller defined it), according to which the Aryans migrated to India from the West and came under the influence of Semitic religions during their eastward journey (Banerjea 1875: 78-112). 
While the Western religions developed further, until they reached their apogee in Christianity, the Eastern Aryans stagnated and were now seeking enlightenment from the West. It was, therefore, not Christianity that threatened Indians with "denationalization," rather, the spread of the Gospel would lead them back to truth (cf. Kopf 1974: 18). Rajnarayan began countering such arguments as early as in the 185 os and, in his Defence of Brahmoism from 1863, he acknowledged that Indians constitute a "branch of the Aryan manifestation" next to the Hellenic, as "there have been but two great manifestations of the religious sentiment in the world, that is the Aryan and the Shemetic." Obviously, Rajnarayan claimed that it was not Christianity but Brahmoism that led to the original Aryan truth contained in the Shastras, a conviction he perceived as vindicated by Friedrich Schlegel, who is quoted stating "that the early Indians possessed knowledge of the true God" (Basu 1863: 9-19).

It is against that background that Rajnarayan invoked the authority of orientalist studies in the sense that he outlined in his Prospectus from 1866. Next to Eduard Röer, Monier Williams, or William Jones, Müller stands out as a markedly important reference. It is well known that Müller's theory concerning the common origin of Aryan civilization was received with great enthusiasm among the Bengali intelligentsia and contributed to the shaping of what Swarupa Gupta has referred to as "cultural Aryan-ness" (Gupta 2009: 23-30; cf. Raychaudhuri 1988: 8). Milinda Banerjee has noted how European scholarship has thus played into contemporary social issues, for instance through an interpretation of caste in terms of race, wherein differences between so-called "high" and "low" castes were presented as immutable consequences of the Aryan conquest of India. Indian nationalist élites were often eager to accept this "idea of Aryan race ancestry," which "gave them a supposed civilizational parity with the Europeans." This interpretation of caste was also employed by British administrators to claim that India was in need of British tutelage (Banerjee 2018: 291).

Invocation of orientalist scholarship on "the Aryans" consequently had a significant socio-political connotation. This is important for an understanding of the centrality of the disputed origin of religion and its true meaning, as Rajnarayan was concerned with inverting the authority usually attributed to the "Western branch" of the Aryan family. Müller, on the other hand, was of course convinced that Europeans represented the "manly" or mature stage in the development of the Aryans, while Indians still excelled in the "meditative and transcendent" sphere of "intellectual activity" (Müller 1883: 117-118). Yet, that Müller's program of "Comparative Theology" was in fact intertwined with its Unitarian-Transcendentalist and Brahmo counterparts is well known (e.g., Hatcher 1999:120-122). In the preface of his Introduction, he particularly lauded 
the efforts of the American Transcendentalists and Unitarians, and praised Channing when he pointed out where not to look for the essentials of religion: "Not in the catechisms, or the articles, not even in the so-called creeds or confessions of faith which, if they do not give us an actual misrepresentation of the doctrines which they profess to epitomise, give us always the shadow only, and never the soul and substance of a religion" (Müller 1873: 102-103, cf. ix). Müller's favorable stance towards Keshab and his followers becomes tangible in his enthusiastic engagement with "the Declaration of Principles by which the church founded by Keshub Chunder Sen professes to be guided." Müller noted that "we might learn something from those whom we are so ready to teach" (Müller 1873: 6-7).

There is a considerable resemblance between Müller's conceptualization of a science of religion and that of Rajnarayan. For instance, Müller was convinced that there was "a faculty of faith in man, independent of all historical religions" (Müller 1873: 17) and insisted that its study be approached without bigotry and partisanship. While he admitted that a "scientific" study of religion "entails losses, and losses of many things which we hold dear," he asserted that "it does not entail the loss of anything that is essential to true religion" (Müller 1873: 10; my emphasis). He too aimed at unraveling the development of true religion beginning with its "Aryan" originators, while stressing that this development was often characterized by "degradation" or, more precisely, a "dialectic growth and decay" (Müller 1873: 168-173, 274). Similar to Rajnarayan, this implied a certain hierarchy of religious traditions, whose diversity should yet be respected and approached without animosity. However, a sharp contrast to Rajnarayan emerges because Müller placed Christianity at the very top of that hierarchy. In fact, he was quite aware of Rajnarayan's parallel efforts to allocate that place to Hinduism when he warned that "a comparative study of religions has become a necessity. If we were to shrink from it, other nations and other creeds would take up the work. A lecture was lately delivered at Calcutta, by the minister of the Adi-Samāj (i.e. the Old Church), 'On the Superiority of Hinduism to every other existing Religion"” (Müller 1873: 33-34). Appalled by Rajnarayan's endeavor, he concluded that those "who would use a comparative study of religions as a means for debasing Christianity by exalting the other religions of mankind, are to my mind as dangerous allies as those who think it necessary to debase all other religions in order to exalt Christianity. Science wants no partisans" (Müller 1873: 37).

As we will see below, Müller's agenda shifted towards a proclamation of the Upanishads as the repository of pure, true religion, but his approach to Christianity and Hinduism was diametrically opposed to that of Rajnarayan. I will now further complicate these agreements and differences by considering 
another player in the debates about true religion and its scientific study, namely, Theosophy. This is particularly instructive because Theosophists enthusiastically engaged with Rajnarayan's propagation of the superiority of Hinduism, as well as his rejection of Christianity, and of Christian missionaries in particular. Similar to Rajnarayan and other Brahmos, Theosophists had an ambivalent relationship with orientalist studies. These aspects explain why Rajnarayan chose to engage with Theosophy in the 188os. In turn, the ensuing disagreements and disappointments represent another crucial piece of the puzzle that is the nineteenth-century struggle over religion, dharma, and Hinduism.

If Rajnarayan's writings have demonstrated the global entanglement of Brahmo discourse about dharma, the Theosophical Society will provide more insights into the global debates about the relationship between religion and science, in which another subject played a crucial role: esotericism (Strube 2021; Strube 2020a; cf. Bergunder 202ob; Bergunder 2016). Rajnarayan's engagement with Theosophy illustrates the ambiguous role of Theosophy within Indian "reform" movements and "Hindu revivalism." Furthermore, the conflict between Rajnarayan and leading Theosophists reveals instructive disparities, conflicts, and rivalries, which enable consideration of the agency of learned Indians under colonialism (Strube forthcoming-c).

The Theosophical Society was founded in New York in 1875 by the illustrious Helena Petrovna Blavatsky, Henry Steel Olcott, and William Quan Judge (for historical overviews, see Hammer \& Rothstein 2013). Most of its members had backgrounds in Spiritualism, which emerged within a radical reformist, often socialist, context and became a major trend in the middle of the century. The Spiritualist conviction that communication with the spirit world provided proof of the existence of the soul and the afterlife attracted a great variety of people, including renowned scientists such as Alfred Russell Wallace and leading socialists such as Robert Owen. However, the Theosophists soon began to polemically distance themselves from Spiritualist practices and instead tended to invoke the notion of "occultism" and its inherent insistence on the need for "initiation" into the esoteric wisdom required for the correct employment of the occult forces that Spiritualist allegedly dabbled with. This went hand in hand with an increasing orientation towards "the East" and the quest for initiation into the mysteries of the ancient Aryan wisdom guarded in India (Strube 2017; Rudbøg \& Sand 2020; Hanegraaff 2020). 
It is for this reason that the Theosophical leaders moved to Bombay in February 1879. After a short-lived alliance with Dayananda Sarasvati's Ārya Samāj, they relocated their headquarters to Adyar near Madras at the end of 1882. From the beginning, they had formed far-reaching ties with both Indians and members of the colonial administration, including Alfred Percy Sinnett and Allan Octavian Hume. Within years, Theosophy became a major cultural and political force in India, which is why John Nicol Farquhar devoted the longest part of his well-known Modern Religious Movements in India to it (Farquhar 1929: 208-291). Its influence arguably peaked when Annie Besant, president of the Society from 1907, was elected president of the Indian National Congress in 1917. Significantly, Theosophical ideas inspired numerous prominent Indians, including Gandhi (Bevir 2000; Bevir 2003; Bergunder 2014a), and became very successful within the intellectual milieu of Bengal, where a preoccupation with Spiritualism and, as we have seen, currents such as Transcendentalism were already well-established (Strube forthcoming-b; Bhatia 2020). Although largely neglected by previous scholarship, this context has a particular relevance for the subject at hand. As John A. Stevens has remarked, Unitarianism and Brahmoism drew on a long history of shared traditions, including Theosophy, Spiritualism, mesmerism, and Freemasonry (Stevens 2018: 50).

A major factor for Theosophy's success was its enthusiastic attitude towards the supposed Aryan wisdom of India. As early as March 30, 1879, the Indian Mirror expressed its astonishment that the Theosophists "had come to learn and not to teach," that they "have proclaimed themselves brethren in every sense of the term, and there can evidently be no question of race-antagonism to mar the pleasant re-unions." They had "done what no Englishmen have ever thought of doing during their more than a century and-a-half's administration of this country: they have dared openly to mix with us as equals. Here is something to be grateful for." The Society put down institutional roots in Bengal in March 1882 and on April 6, the Bengal Theosophical Society was formally established at the estate of Yatindramohan Tagore (Olcott 19oo: 341-342). Its early members included eminent Bengalis such as Pyarichand Mitra, Shishirkumar Ghosh, Shyamashankar Ray, Narendranath Sen (editor of the Indian Mirror and a cousin of Keshab), Mohinimohan Chattopadhyay, Svarnakumari Devi, and Dvijendranath Tagore (son of Debendranath, eldest brother of Rabindranath, and secretary of the Ādi Brāhma Samāj and the Hindu Mela of 1867, who now became vice-president of the Bengal Theosophical Society). On April 5, Olcott gave a public lecture at the Calcutta Town Hall, wherein he proclaimed Theosophy as "the Scientific Basis of Religion." He berated the influence of Western education and ironically referred to the holders of BA degrees as "Bad 
Aryans." Instead, "Young India" would be well advised to turn to the wisdom of the ancient Aryan rishis (Olcott 1885: 117). Olcott specifically praised the ancient "Yoga Vidya," which was supposedly confirmed by modern Western science, albeit imperfectly. Like many Theosophists, he called for a synthesis of ancient Aryan wisdom and modern science, according to the "spirit of the nineteenth century" (Olcott 1885: 149). One consequence was the subsequent establishment of "Hindu schools" and other educational institutions in the years to follow.

It will not come as a surprise that many contemporaries counted the Theosophists among the "revivalists," their strong social reformist thrust notwithstanding (on this ambivalence, see Strube forthcoming-b). Like the numerous and influential Indian "orthodox" or "revivalist" societies that were established around the same time, Theosophists strived for the resurrection of sanātana dharma, the "eternal dharma." Accordingly, the Bengal Theosophical Society at some point referred to itself as The Bengali Theosophical Society for the Promotion of the Meaning of the Eternal Aryan Dharma (Sanātan Āryyadharmmapracārārtha Bangadeśíỳa Tattvasabhā) before later changing its name to The Society for the Investigation of Tattva (Tattva-jijñāsusabhā). Notably, common translations of "Theosophy" into Bengali were brahmavidya, tattvavidya, and dharmatattva. These signifiers and the associated debates about the meaning of dharma put the Theosophists into close alignment with both conservative and traditionalist Indians, as well as with Rajnarayan, whose views had similarly approached those of these cohorts in the preceding years. Tellingly, Olcott can be found among the founding members of the conservative Bhārat Dharma Mahāmaṇụal. Rameshwar Singh, its patron and general secretary, was a supporter of Theosophy and co-founded the Banaras Hindu University in 1911 with Besant. Lakshmeshwar Singh, his elder brother and predecessor, became a member of the Society as early as 1883 and generously supported the Theosophical Kashi Tattva Lodge in Benares - an act documented in the report of the second-anniversary meeting of the lodge, which was printed, significantly, by the Vedavyasa Press, then run by the prominent conservative pandit Shashadhar Tarkacuramani (Strube forthcoming-b).

Rajnarayan and many Theosophists, especially Blavatsky, were united in an outspoken disdain for Christian missionaries, and church Christianity in general. They called for "national education" and invoked the wisdom of the ancient Aryan rishis. Moreover, they shared an ambivalent relationship with European orientalists in their goal to establish a "scientific basis of religion." In the words of Jason Josephson-Storm, Theosophy can be viewed as "a historical doppelgänger" of Religionswissenschaft (in Müller's sense of the word), "a parallel movement, that drew from nearly the same social sphere, shared 
many intellectual objectives and political coordinates, and for a time was more successful in recruiting members and placing different religions in dialogue" (Josephson-Storm 2017: 115-116).

This is underlined by an exchange between Olcott and Müller that began in 1888 and unfolded over several years. In 1893, Müller published a volume titled Theosophy, or Psychological Religion, in which he resolutely refuted the Theosophical Society (Müller 1893: xvi) - his personal correspondence with Olcott was, however, far more amicable. He even tried to "convert" his interlocutor to his own take on "theosophy," noting that he would have directed the same criticism "against myself and my best friends, when I saw that they were seeking for the truth but were going on a wrong road to find it. [...] Once more, you can do a great deal of good if you will help the people in India to discover and recover the treasure of truth in their old Brahma-sophy" (Müller 19o2: 294-295). This remarkable parallel to brahmavidya is further underscored by the fact that Müller had at that point arrived at the conviction that the true ur-religion could be found in the Upanishads. Accordingly, he wrote in a letter that "if the Theosophical Society means to do any real good, it must take its stand on the Upanishads, and on nothing else" (Müller 1902: 233).

Previous scholarship has mostly focused on how Westerners such as Olcott and Müller have talked about Indians within the context of Theosophy and early Religionswissenschaft, while little attention has been paid to the role of Indians in actively shaping how they were understood. As the reader might surmise from what has been discussed so far, this role was anything but marginal. However, exploring the relationship between Western and Indian Theosophists, as well as their manifold interlocutors, is challenging because of several significant ambiguities and contradictions. Certainly, Theosophy provided Indians with an exceptional level of agency that, as illustrated by the Indian Mirror, did not pass unnoticed. At the same time, racial stereotypes, and more or less implicit racial hierarchies, were by no means absent from the Society (Strube forthcoming-c). Still, it would be too simplistic to focus exclusively on what Viswanathan has called the "ventriloquism" performed by Theosophical leaders - meaning that Theosophists such as Blavatsky tended to allude to the esoteric wisdom allegedly communicated to them by "hidden Masters," the so-called "Mahatmas." This puppeteering not only effectively presented their own ideas as "Indian," it also established authority over viewpoints held by "actual" Indians (Viswanathan 1998: 177-207; cf. Viswanathan 200o). While every historian of Theosophy should be mindful of these dynamics, Viswanathan tends to overemphasize the oppressive colonial structures within Theosophy, while neglecting the agency of its Indian members and interlocutors. One outcome is that she, like other historians of Theosophy, 
focuses on white, Western Theosophists and Anglophone sources, without paying sufficient attention to "non-Westerners."

An extraordinary episode involving Rajnarayan serves to illuminate these intricacies. It will be recalled that he had published his famous speech on "The Superiority of Hinduism" (Hindudharmmer śreșthatā) in 1872; that the Theosophists had entered an intellectual landscape marked by rivalling Brahmo factions; and that representatives of all these factions interacted with or even joined the Society, including Narendranath (and adherent of Keshab) and Dvijendranath (of the Ādi Samāj). The fact the Theosophists were actively concerned with reviving the ancient Aryan dharma played directly into these dynamics, which received new impetus through, not least, Rajnarayan's lecture - an event often taken to mark the actual birth of "Hindu revivalism" (Sen 1993: 29). That Rajnarayan found himself in allegiance with conservative pandits was somewhat embarrassingly noted in his memoirs (Basu 1909: 88-89; cf. Kopf 1974: 23; Hatcher 1999) and accentuates the significance of his subsequent engagement with the strange newcomers who also appeared to propagate the brahmavidya $\bar{a}$ that he had elucidated in his Dharmmatattvadīpikā, stressing its Aryan antiquity, purity, superiority, and scientificness. This proximity appeared even closer in light of the Theosophists' fascination with "Yoga Vidya," as Rajnarayan elevated "the doctrine of Yoga or communion" with God in his Essential Religion (Bose 1886a: 9) and often alluded to the workings of energy or power (śakti), as well as electricity and magnetism. Such concepts were of major interest to the Theosophists, who aimed to master the "occult forces" purportedly employed through yogic techniques (e.g., Basu 1866: 9-11; Bose 1878: 16; cf. Strube forthcoming-b; Strube 202ob; Strube 2020a).

In short, Blavatsky and Rajnarayan had a lot to talk about. Indeed, the latter chose to publish his own full English translation of Hindudharmmer śreșthatā in the Society's flagship journal, The Theosophist, between June and November 1882. Introducing Rajnarayan's translation, Blavatsky expressed her wish to invite a Brahmo to represent "Hindu Theism." After lauding Rammohan with the remark that "no country can boast a purer or holier son than was this Indian reformer," she discussed the schisms among the Brahmos, levelling harsh criticism against Keshab while singling out the Ādi Samāj as being "nearest [...] to being orthodox." This assessment was based on the view that the Ādi Samāj retained a good deal of what is excellent in Hindu "national religion" and defined Hinduism as pure and essential Theism (Blavatsky 1882: 215-216). Given Blavatsky's hostile stance towards Christianity, this is not surprising. Rajnarayan was portrayed as a "venerable friend" and responded in a similarly cordial tone, lauding the "esteemed journal" that had provided him with a platform (Bose 1882c: 242). 
A direct line runs from the original publication of Hindudharmmer śresțhatā in 1872 , via the Hints in 1878 , to the welcoming forum provided by the Theosophists. Most scholarship on Theosophy has presented the Society's "influence" in terms of the "export" into India of Western scientific-mindedness, rationalism, orientalist scholarship, and preoccupation with yogic occult forces. However, Rajnarayan's engagement with Theosophy clearly demonstrates that such a perspective is misleading. He communicated the ideas that he had developed over the course of the preceding decades - also prior to the writings of Müller - to his Theosophical interlocutors, which is only underlined by the fact that his arguments in "The Superiority of Hinduism to Other Existing Religions" do not contain much new in addition to what has been already been discussed in the previous sections of this article. Similar observations can be made about the focus on the Upanishads, as represented by Müller, who quarreled about this very subject with Olcott. From the beginning, Rajnarayan put a strong emphasis on the Upanishads as the scriptures of true Vedanta, while also invoking the Brahmanical tradition particular to Bengal: for instance, he included positive references to the Tantras that starkly contrasted with other "reformers," such as the followers of the Ārya Samāj (e.g., Bose 1882c: 246-247, 14; cf. the discussion of that context in Strube forthcoming-b). At the same time, he praised his Unitarian friends, including Cobbe, "the English Brahmica, or Female Theist," and Parker (Bose 1882a: 284).

Rajnarayan presented a list of points proving his claims of the superiority of Hinduism, several of which are relevant to our concerns. For instance, the first point argues that Hinduism was not derived from the name of a man: "This is an evidence of its broad character. Religion is catholic, and so it ougt noth [sic] to go by the name of any person. The Hindus, therefore, call their religion the Sanatana, or the eternal or underived religion" (Bose 1882a: 286). Furthermore, Rajnarayan highlighted that Hinduism "teaches Yoga or intimate and unfailing communion with God" (Bose 1882a: 286). He also singled out that Hinduism "teaches Yoga or intimate and unfailing communion with God" (Bose 1882a: 286-287), which certainly aroused the interest of his new Theosophical audience. Rajnarayan also argued that "Hinduism is older than any other religion, and it sprung long before the rise of history," with other religions branching out from it like from the trunk of a tree. It is, therefore, universal and unsectarian, "because its truths are common to all religions, and it admits men of all nations and races within its place. Hinduism has, by progressive development, assumed in Brahmoism a form which is perfectly catholic." It was also appropriate for modern times: "In the old days, knowledge restricted to forest dwellers. But nowadays, knowledge is being diffused among all ranks of society. Instruction of the mass in the knowledge of the One True God is needed" (Bose 1882b: 
34). In contrast to his earlier writings and the positions taken by many other Brahmos, Rajnarayan resolutely affirmed his "Hindu" identity: "We should not, therefore, forsake the name of Hindu as long as the last drop of Aryan blood runs in our veins" (Bose 1882b: 34). A reinvigorated Hinduism would give rise to a superior "religious and moral civilization," which "will stand as the best and the foremost of all nations of the earth" (Bose 1882b: 35). The pamphlet dramatically ends with a famous song to the "glory to Ind," which had been sung at the Hindu Mela.

Curiously, the exchange was not all roses and sunshine. In June 1883 , Blavatsky published an exceptionally comprehensive, if respectful critique of Rajnarayan's Essential Religion, which she had recently read in the Tattvabodhini Patrikā. Blavatsky disagreed with the Brahmo's opinion that differences of religion always and necessarily exist in the world, accusing him of "a certain sectarian, hence selfish feeling, one against which our Society is forced to fight so desperately" (Blavatsky 1883: 213-214). While viciously attacking Christianity, she rejected the proliferation of any particular religion. In August, Rajnarayan politely asserted one's "duty" to disseminate, in a gentle and tolerant manner, that which one considers to be true. Religion was not merely emotion but also science, thus it was not a matter of personal whim but of truth, which he substantiated with reference to his Hints (Bose 1883a: 274). Professing his belief "in the strong power of will, mesmerism and yoga powers," he reaffirmed his friendly attitude to Theosophists but advised them to "keep Theosophy and Theology distinct from each other" and reconsider their positive attitude to atheism and scepticism (Bose 1883a: 275).

Blavatsky added a remarkable footnote to this letter, stating that "the affliction of India is, that it lost theosophy when the persecuted adepts had to fly beyond the mountains. And true religious living can never be again prevalent until their help is invoked to illumine the Shastras." She reminded her "Brother" that the Theists of the Âdi Samāj had failed, after many years, to win "the Hindus from their exoteric worship - we think, because neither of them has had the Yogi power to prove practically the fact of there being a spiritual side to nature." Only "the esoteric philosophy, or rather theosophy of Gautama Buddha and Sankaracharya prove," in a practical and scientific manner, "the undeniable presence of a living God in man himself," regardless of one's faith (Bose 1883a: 275). With this move, Blavatsky effectively declared authority over Rajnarayan by invoking the esoteric truth communicated to her by hidden Mahatmas, while suggesting a lack thereof among Brahmos, as evidenced by the absence of their yogic powers - a case of ventriloquism indeed.

Yet this is not where it all ended. In December 1883, Rajnarayan retaliated by pointing out that the Theosophists themselves were, in fact, proselytizing: 
"But do you not endeavour to prevail upon people to believe in Occultism and the existence of Spirit? If you do not do so, what is the use of these Theosophical Societies? Is not this a kind of religious propagation?" As for yogic powers, he wished to inform Blavatsky that the members of the Ādi Samāj "believe that the highest Yoga is the concentration of mind upon God even amidst the transaction of worldly affairs," which was illustrated by his own "Superiority of Hinduism" that referred to the "best of all yogas, the real Raj yoga." He differentiated this superior yoga from its "theosophic" variety, which "has its use": "It enables us to show that the people of Asia are possessed of scientific knowledge to which European science is as nothing" (Bose $1883 \mathrm{~b}$ : 75 ). With reference to his health, he politely concluded "this very interesting discussion."

\section{Conclusion and Outlook}

Rajnarayan's response inverted Blavatsky's claim for authority. In a subtle yet effective move, he subordinated Theosophical yoga to the superior "Raj yoga" of the Brahmos, juxtaposing the superiority of Hinduism to the inferior "European science," of which Blavatsky might very well have been considered a representative (for the intricate debates about yoga, which unfolded within the exact same context, see Strube forthcoming-b). The crucial point is that we here see the workings of the strategy that Rajnarayan had laid out in his 1866 Prospectus: to engage with "Western" thought where it serves to prove the superiority of Indian culture. In this sense, Theosophy had "its use." Evidently, both Blavatsky and Rajnarayan were referring to the same signifiers and identity markers to assert their proficiency of esoteric yogic wisdom and power, revolving around the progressive revival of ancient Aryan civilization and the striving towards a "brotherhood of men" based on the essence of Truth common to humanity.

These notions were part of a global discourse about religion, its relationship to science, and how it pertained to race and nationality. When viewed in this light, important entanglements between the discourses on "religion" and "dharma" come to the fore: the centrality of "its" supposed common and universal roots; its historical development marked by progress and decay; the resulting obfuscation of its "true" core through human error; the immediate need for its restoration; proving the accordance of "true" religion with science and philosophy; and forming the basis of a new, better society. It is the idea of a hidden true core inaccessible to "the masses" that formed one crucial connection to the notion of esotericism, and with it claims to power and authority in interpreting the truth. This becomes graspable in the clash between Blavatsky 
and Rajnarayan over the actual content of core and shell, of esoteric and exoteric, but also in the skirmish between Müller and Olcott.

The negotiation or contestation of the meaning of such notions did not run unidirectionally, nor did the Theosophists "export" them into Indian discourse - quite the contrary. Upon their arrival in India, the Theosophists became subject to manifold interests and entangled in debates that had already been going on for decades. These debates had, in turn, already unfolded within a global context, thus forming the structures and conditions for the fruitful encounter between learned Indians and the newly arrived Theosophists.

This helps to explain the remarkable parallels between the Brahmo, Unitarian, Transcendentalist, Theist, Theosophical, and orientalist approaches to religion that have been surveyed in this article. Like religion, dharma was discussed in light of its ancient origin, its development involving decay and progress, its current position on science, and its role for the forging of a future society. The specifics of these ideas were hotly contested and revolved, for instance, around the role of the Upanishads, the nature of the divine and its relation to the material world, and epistemological and practical differentiations between exoteric (error) and esoteric (truth). Although actors such as Rajnarayan, Müller, Olcott, and Blavatsky differed on several crucial aspects, their positions were remarkably close to one another. This tangle of exchanges demonstrates the still neglected global dimension of the emergence of religious studies.

The genealogical perspective of global religious history can help to unravel these intricacies fruitfully and thus contribute to the revision of presentday scholarly and non-scholarly positionalities that, more often than not, tend to assume clear boundaries between orientalist scholarship, theology, Theosophy, and Brahmoism. The historical sources strongly contradict such perceptions. A crucial challenge lies in establishing a diachronic perspective to further understand how such positioning and identity markers were negotiated, and how they can be related to the period prior to the nineteenth century. Indeed, both global history and religious studies face a range of either identical or interrelated challenges when applying their toolkits in this regard. The issue of "reform" versus "orthodoxy," or "revival" of the latter, directly relates to the meaning of "modernity." Hatcher has recently argued that we ought to think of "modern Hinduism as emerging - rather than divorcing itself - from premodern modes of innovation" (Hatcher 2020: 32). Rather than viewing the language of revival and renaissance in terms of a break with the past or the dawning of a new age, it would then be necessary to also consider the early colonial period from roughly $175^{\circ}$ to $185^{\circ}$ as a "crucial moment of transition" (Hatcher 2020: 33-41). Although I do not subscribe to Hatcher's proposal that 
we should dismiss the notion of reform from scholarly vocabulary altogether, his overall argument harmonizes well will the potential of global religious history to extend diachronic research. From this perspective, "reform" remains a central historical category employed and contested by rivaling actors. As an empty signifier, it does not have a fixed meaning, but it does highlight the contemporary perception of radical reconfigurations of related notions such as religion, dharma, Aryan, or science. Such perceptions of reform and its antagonists must themselves be the subject of historical inquiry.

For this, it is essential to consider local conditions for how these notions were constantly re-negotiated, including those that have been shaped before the establishment of European colonialism in South Asia. Yet, as Bergunder emphasized, taking into account the "precolonial" period must not equate to vaguely referring to Indian traditions thousands of years old, the continuity of which is often simply presupposed (Bergunder 2020a: 88-89). Studies conducted in such a spirit could shine further light on how actors such as Rajnarayan or Rammohan developed their ideas against diachronic regional backgrounds, including Persian learning, the elucidation of dharmaśästra particular to Bengal, and Navya Nyāya. This would allow for further finegrained studies of how European orientalist studies and philosophies, such as Kantianism and German Idealism, were negotiated (cf. Sartori 2007; Sartori 2008). Most fundamentally, this would further elucidate how different historical actors could enter dialogues so effectively and shape ideas that still inform us in the present day. Not least, they contributed to the emergence of the academic discipline to which this journal is dedicated.

\section{References}

Banerjea, Krishna Mohun (1875). The Arian Witness: Or the Testimony of Arian Scriptures in Corroboration of Biblical History and the Rudiments of Christian Doctrine. Calcutta/ London: Thacker, Spink \& Co./Trübner and Co.

Banerjee, Milinda (2018). The Mortal God: Imagining the Sovereign in Colonial India. Cambridge: Cambridge University Press.

Basu, Rajlnarayan (1863). A Defence of Brahmoism and the Brahmo Samaj: Being a Lecture Delivered at the Midnapore Samaj Hall on the 21st June 1863. Midnapore.

Basu, Rājlnārāẏạ̣ (1866). Dharmmatattvadīpikā. Calcutta: Giriś-Bidyāratna.

Basu, Rājlnārāẏạ (1909). Âtma-carit. Calcutta: Kuntaline Press.

Basu, Rajnarayan (1870). The Adi Brahma Samaj: Its Views and Principles. Calcutta: Adi Brahma Samaj Press. 
Bayly, Christopher A. (2004). The Birth of the Modern World, 1780-1914: Global Connections and Comparisons. Malden/Oxford: Blackwell.

Bergunder, Michael (2006). Die Bhagavadgita im 19. Jahrhundert. In: M. Bergunder (ed.), Westliche Formen des Hinduismus in Deutschland, Halle: Franckesche Stiftungen, pp. 187-216.

Bergunder, Michael (2014a). Experiments with Theosophical Truth: Gandhi, Esotericism, and Global Religious History. Journal of the American Academy of Religion 82, pp. 398-426.

Bergunder, Michael (2014b). What is Religion? The Unexplained Subject Matter of Religious Studies. Method and Theory in the Study of Religion 26, pp. 246-286.

Bergunder, Michael (2016). 'Religion' and 'Science' Within a Global Religious History. Aries 16 (1), pp. 86-141.

Bergunder, Michael (2020a). Hinduism, Theosophy, and the Bhagavad Gita within a Global Religious History of the Nineteenth Century. In: H. M. Krämer \& J. Strube (eds.), Theosophy across Boundaries: Transcultural and Interdisciplinary Perspectives on a Modern Esoteric Movement, Albany, NY: State University of New York Press, pp. 65-107.

Bergunder, Michael (2020b). Umkämpfte Historisierung: Die Zwillingsgeburt von 'Religion' und 'Esoterik' in der zweiten Hälfte des 19. Jahrhunderts und das Programm einer globalen Religionsgeschichte. In: K. Hock (ed.), Wissen um Religion: Erkenntnis - Interesse: Epistemologie und Episteme in Religionswissenschaft und Interkultureller Theologie, Leipzig: Evangelische Verlagsanstalt, pp. 47-131.

Bevir, Mark (2000). Theosophy as a Political Movement. In: A. Copley (ed.), Gurus and Their Followers, Delhi: Oxford University Press, pp. 159-179.

Bevir, Mark (2003). Theosophy and the Origins of the Indian National Congress. International Journal for Hindu Studies 7 (1/3), pp. 99-115.

Bhatia, Varuni (2017). Unforgetting Chaitanya: Vaishnavism and Cultures of Devotion in Colonial Bengal. New York, NY: Oxford University Press.

Bhatia, Varuni (2020). The Psychic Chaitanya: Global Occult and Vaishnavism in Fin de Siècle Bengal. The Journal of Hindu Studies 13, pp. 10-29.

Blavatsky, Helena Petrovna (1882). Hindu Theism. The Theosophist 3 (9), pp. 215-216. Blavatsky, Helena Petrovna (1883). A Few Thoughts on Some Wise Words from a Wise Man. The Theosophist 4 (9), pp. 213-217.

Bose, Raj Narain (1878). Hints Shewing the Feasibility of Constructing a Science of Religion. Harinabhi: T. N. Chuckerburty.

Bose, Raj Narain (1882a). Superiority of Hinduism to Other Existing Religions: As Viewed from the Stand-Point of Theism. The Theosophist 3 (10), pp. 246-249.

Bose, Raj Narain (1882b). Superiority of Hinduism to Other Existing Religions: As Viewed from the Stand-Point of Theism. The Theosophist 4 (1), pp. 13-16. 
Bose, Raj Narain (1882c). A Theist's View of Buddhism. The Theosophist 3 (10), pp. 242. Bose, Raj Narain (1883a). The Essentials of Religion. The Theosophist 4 (11), pp. 274-275. Bose, Raj Narain (1883b). The God-Idea. The Theosophist 5 (3), pp. $75^{-76}$.

Bose, Rajnarain (1886a). The Essential Religion. Calcutta: Gagaṇ ${ }^{1}$ candra Hom.

Bose, Rajnarain (1886b). Sārdharmma. Calcutta: Gagaṇ candra Hom.

Chatterjee, Gouripada (1986). Midnapore: The Forerunner of India's Freedom Struggle. Delhi: Mittal Publications.

Chatterjee, Partha (2010). Our Modernity. In: Empire and Nation: Selected Essays, New York, NY: Columbia University Press, pp. 136-152.

Conrad, Sebastian (2018). A Cultural History of Global Transformation. In: S. Conrad \& J. r. Osterhammel (eds.), A History of the World, Cambridge, MA: Harvard University Press, pp. 411-659.

Farquhar, John Nicol (1929). Modern Religious Movements in India. London: Macmillan and Co.

Fischer-Tiné, Harald (2018). Marrying Global History with South Asian History: Potential and Limits of Global Microhistory in a Regional Inflection. Comparativ 28 (5), pp. 49-74.

Green, Nile (2015). The Global Occult: An Introduction. History of Religions 54 (4), pp. 383-393.

Gupta, Swarupa (2009). Notions of Nationhood in Bengal:Perspectives on Samaj, c. 18671905. Leiden/Boston, MA: Brill.

Gura, Philip F. (2007). American Transcendentalism: A History. New York, NY: Hill and Wang.

Hammer, Olav \& Mikael Rothstein (eds.) (2013) Handbook of the Theosophical Current. Leiden/Boston, MA: Brill.

Hanegraaff, Wouter (2015). The Globalization of Esotericism. Correspondences 3 (1), pp. 55-91.

Hanegraaff, Wouter (2020). Western Esotericism and the Orient in the First Theosophical Society. In: H. M. Krämer \& J. Strube (eds.), Theosophy across Boundaries: Transcultural and Interdisciplinary Perspectives on a Modern Esoteric Movement, Albany: State University of New York Press, pp. 29-64.

Hatcher, Brian A. (1996). Idioms of Improvement: Vidyasagar and Cultural Encounter in Bengal. Calcutta: Oxford University Press.

Hatcher, Brian A. (1999). Eclecticism and Modern Hindu Discourse. New York, NY: Oxford University Press.

Hatcher, Brian A. (2006). Remembering Rammohan: An Essay on the (Re-)emergence of Modern Hinduism. History of Religions 46 (1), pp. 50-80.

Hatcher, Brian A. (2007). Bourgeois Vedānta: The Colonial Roots of Middle-Class Hinduism. Journal of the American Academy of Religion 75 (2), pp. 298-323. 
Hatcher, Brian A. (2008). Bourgeois Hinduism, or the Faith of the Modern Vedantists: Rare Discourses from Early Colonial Bengal. New York, NY: Oxford University Press.

Hatcher, Brian A. (2020). Hinduism Before Reform. Cambridge, MA/London: Harvard University Press.

Jackson, Carl T. (1981). The Oriental Religions and American Thought:Nineteenth-Century Explorations. Westport/London: Greenwood Press.

Josephson-Storm, Jason Ānanda (2017). The Myth of Disenchantment: Magic, Modernity, and the Birth of the Human Sciences. Chicago, IL/London: University of Chicago Press.

Kopf, David (1974). The Missionary Challenge and Brahmo Response: Rajnarain Bose and the Emerging Ideology of Cultural Nationalism. Contributions to Indian Sociology (NS) 8, pp. 11-24.

Kopf, David (1979). The Brahmo Samaj and the Shaping of the Modern Indian Mind. Princeton, NJ: Princeton University Press.

Krämer, Hans Martin \& Julian Strube (eds.) (2020) Theosophy across Boundaries: Transcultural and Interdisciplinary Perspectives on a Modern Esoteric Movement. Albany, NY: State University of New York Press.

Lal, Vinay (2003). Provincializing the West: World History from the Perspective of Indian History. In: B. Stuchtey \& E. Fuchs (eds.), Writing World History 1800-2000, Oxford: Oxford University Press, pp. 271-289.

Lavan, Spencer (1977). Unitarians and India: A Study in Encounter and Response. Boston, MA: Beacon Press.

Maltese, Giovanni \& Julian Strube (2021). Global Religious History. Method \& Theory in the Study of Religion 33, pp. 229-257.

Mukhopadhyay, Mriganka (2020). Mohini: A Case Study of a Transnational Spiritual Space in the History of the Theosophical Society. Numen 67 (2-3), pp. 165-19o.

Müller, Friedrich Max (1873). Introduction to the Science of Religion: Four Lectures Delivered at the Royal Institution, with Two Essays on False Analogies, and the Philosophy of Mythology. London: Longmans, Green, and Co.

Müller, Friedrich Max (1883). India, What Can It Teach Us? London: Longmans, Green, and Co.

Müller, Friedrich Max (1893). Theosophy, or Psychological Religion. London: Longmans, Green, and Co.

Müller, Friedrich Max (1902). The Life and Letters of the Right Honourable Friedrich Max Müller. London: Green and Co.

Mullick, Sunrit (2010). The First Hindu Mission to America: The Pioneering Visits of Protap Chunder Mozoomdar. New Delhi: Northern Book Centre.

Myerson, Joel, Sandra Harbert Petrulionis \& Laura Dassow Walls (2010). The Oxford Handbook of Transcendentalism. New York, NY: Oxford University Press. 
Nandy, Ashis (1996). History's Forgotten Doubles. History and Theory 34 (2), pp. 44-66. Newman, Francis William (1858). Theism, Doctrinal and Practical, or Didactic Religious Utterances. London: John Chapman.

Olcott, Henry Steel (1885). Theosophy, the Scientific Basis of Religion. In: H. S. Olcott (ed.), Theosophy: Religion and Occult Science, George Redway: London, pp. 116-165.

Olcott, Henry Steel (1900). Old Diary Leaves: The Only Authentic History of the Theosophical Society, Second Series, 1878-83. London/Madras: The Theosophical Publishing Society/Theosophist Office.

Osterhammel, Jürgen (2014). The Transformation of the World: A Global History of the Nineteenth Century. Princeton, NJ: Princeton University Press.

Raychaudhuri, Tapan (1988). Europe Reconsidered: Perceptions of the West in Nineteenth Century Bengal. Delhi/New York, NY: Oxford University Press.

Robinson, David M. (2015). Emerson, the Indian Brahmo Samaj, and the American Reception of Gandhi. In: D. LaRocca \& R. Miguel-Alfonso (eds.), A Power to Translate the World: New Essays on Emerson and International Culture, Lebanon, NH: Dartmouth College Press, pp. 43-6o.

Rudbøg, Tim \& Erik Reenberg Sand (2020). Imagining the East: The Early Theosophical Society. New York, NY: Oxford University Press.

Sarkar, Jadunath (1909). Rajnarain Bose, Grandfather of Nationalism in India. Modern Review 5, pp. 311-319.

Sartori, Andrew (2007). Beyond Culture-Contact and Colonial Dicourse: 'Germanism' in Colinial Bengal. Modern Intellectual History 4 (1), pp. 77-93.

Sartori, Andrew (2008). Bengal in Global Concept History: Culturalism in the Age of Capital. Chicago, IL: University of Chicago Press.

Sen, Amiya P. (1993). Hindu Revivalism in Bengal, 1872-1905: Some Essays in Interpretation. Oxford/Delhi: Oxford University Press.

Stevens, John A. (2018). Keshab: Bengal's Forgotten Prophet. New York, NY: Oxford University Press.

Strube, Julian (2017). Occultist Identity Formations Between Theosophy and Socialism in Fin-de-Siècle France. Numen 64 (5-6), pp. 568-595.

Strube, Julian (2020a). Hinduism, Western Esotericism, and New Age Religion in Europe. In: K. A. Jacobsen \& F. Sardella (eds.), Handbook of Hinduism in Europe, Leiden/Boston, MA: Brill, pp. 152-173.

Strube, Julian (2020b). Yoga and Meditation in Esoteric Traditions. In: S. Newcombe \& K. O’Brien-Kop (eds.), Routledge Handbook of Yoga and Meditation Studies, Abingdon: Routledge, pp. 130-145.

Strube, Julian (2021). Towards the Study of Esotericism Without the 'Western': Esotericism from the Perspective of a Global Religious History. In: E. Asprem \& J. Strube (eds.), New Approaches to the Study of Esotericism. Leiden/Boston, MA: Brill, pp. $45^{-66 .}$ 
Strube, Julian (forthcoming-a). Tantra. In: E. Asprem (ed.), Dictionary of Contemporary Esotericism, Leiden/Boston, MA: Brill.

Strube, Julian (forthcoming-b). Global Tantra: Religion, Science, and Nationalism in Colonial Modernity. Oxford/New York, NY: Oxford University Press.

Strube, Julian (forthcoming-c). Theosophy, Race, and the Study of Esotericism. Journal of the American Academy of Religion.

Versluis, Arthur (1993). American Transcendentalism and Asian Religions. Oxford: Oxford University Press.

Viswanathan, Gauri (1998). Outside the Fold: Conversion, Modernity, and Belief. Princeton, NJ: Princeton University Press.

Viswanathan, Gauri (2000). The Ordinary Business of Occultism. Critical Inquiry 27 (1), pp. 1-20.

Wenzlhuemer, Roland (2017). Globalgeschichte schreiben:Eine Einführung in 6 Episoden. Konstanz/München: UVk Verlagsgesellschaft.

Zastoupil, Lynn (2010). Rammohun Roy and the Making of Victorian Britain. New York, NY: Palgrave Macmillan. 